\title{
LIGNANS FROM THE AERIAL PARTS OF HAPLOPHYLLUM TUBERCULATUM (FORSSK) A. JUSS
}

\author{
D. T. A. Youssef
}

Department of Pharmacognosy, Faculty of Pharmacy, Suez Canal University, Ismailia 41522, Egypt

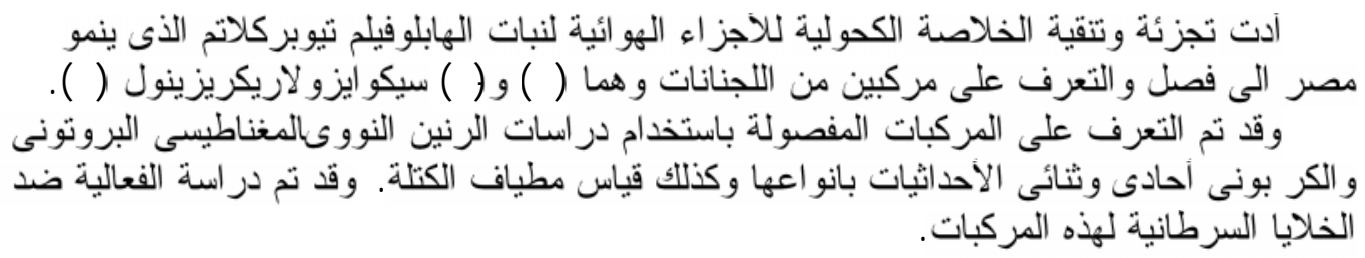

Bioassay-guided investigation of the aerial parts of Haplophyllum tuberculatum (Forssk) A. Juss grown in Egypt led to the isolation and characterization of two lignans, 1 and 2 [(-)secoisolariciresinol]. The structural mapping of the isolated compounds was established on the basis of intensive $1 D$ and 2D NMR studies. The anticancer activity of the isolated compounds was reported.

\section{INTRODUCTION}

The genus Haplophyllum (Rutaceae) includes about 70 species spread out from the Mediterranean to Eastern Siberia. ${ }^{1}$ It is represented in Egypt by three species namely, $H$. tuberculatum (Forssk) A. Juss, H. obovatum (Hochst. ex. Boiss), and H. longifolium Boiss. ${ }^{2}$ Previous study on $H$. tuberculatum (Forssk) A. Juss resulted in the isolation of several alkaloids, ${ }^{3-6}$ lignans, ${ }^{5-10}$ and flavonoids. ${ }^{10} \mathrm{H}$. tuberculatum (Forssk) A. Juss is applied in the Egyptian folk medicine for treatment of nausea, constipation, malaria and gastric pain. ${ }^{11}$

In this work we report the isolation and structural determination of two lignans $\mathbf{1}$ and $\mathbf{2}$ [(-)-secoisolariciresinol]. The structural determination of the isolated compounds was based on extensive study of $1 \mathrm{D}\left({ }^{1} \mathrm{H}\right.$ and $\left.{ }^{13} \mathrm{C}\right)$ and 2D (COSY, HMQC, HMBC) NMR spectra. The anticancer evaluation of the compounds using in vitro disk diffusion assay against a panel of cancer cell lines was reported. Compound $\mathbf{1}$ showed selectivity against human solid tumor (Human Lung Cancer, H-125M).

\section{EXPERIMENTAL}

\section{General experimental procedures}

MPs were uncorrected. Optical rotations were measured on JASCO DIP-1000 digital polarimeter. ${ }^{1} \mathrm{H}$ and ${ }^{13} \mathrm{C}$ NMR spectra were recorded on a Varian Unity 500 spectrometer at $500 \mathrm{MHz}$ for ${ }^{1} \mathrm{H}$ and $125 \mathrm{MHz}$ for ${ }^{13} \mathrm{C}$, respectively. EIMS data were obtained with a JEOL JMS-700T mass spectrometer. Medium pressure Liquid chromatography (MPLC) was conducted on pre-packed silica column (LiChroprep Si 60, 310 x $25 \mathrm{~mm}, 40-63 \mu \mathrm{m}$, Merck). Pre-coated silica gel $60 \mathrm{~F}_{254}$ plates (Merck) were used for TLC.

\section{Plant material}

Flowering plant materials were collected in May 2000 from El-Kharga, the New Valley, Egypt. The plant materials were air-dried in the shade. The plant was identified by Prof. Dr. A. Fayed, Professor of Plant Taxonomy, Faculty of Science, Assiut University. A voucher specimen is deposited in the herbarium of the Department of Pharmacognosy, Faculty of Pharmacy, Suez Canal University. 


\section{Extraction and Isolation}

The powdered air-dried aerial parts (1.3 $\mathrm{kg}$ ) were extracted by maceration with $\mathrm{MeOH}$ $(3 \times 3000 \mathrm{~mL})$ at room temperature. The methanolic extract $(83 \mathrm{~g})$ was diluted with water $(120 \mathrm{~mL})$ and successively extracted with hexane $(4 \times 300 \mathrm{~mL}), \mathrm{CH}_{2} \mathrm{Cl}_{2}$ (4 x 300 $\mathrm{mL})$, ethyl acetate $(4 \times 300 \mathrm{~mL})$ and finally with n-butanol ( $4 \times 300 \mathrm{~mL})$. Both $\mathrm{CH}_{2} \mathrm{Cl}_{2}$ and EtOAc extracts were combined together and the residue $(7.2 \mathrm{~g})$ was subjected to VLC flash chromatography on silica gel column (15 x 10 $\mathrm{cm})$ using hexane-EtOAc gradients.

Fractions eluted with hexane-EtOAc (70:30 - 50:50) were combined together and the residue $(2.1 \mathrm{~g})$ was subjected to column chromatography on silica gel column using hexane-EtOAc gradients. Fractions eluted with hexane-EtOAc (20:80) were collected together and the residue $(80 \mathrm{mg}$ ) was subjected to a pre- packed silica MPLC (LiChroprep Si 60, 310 x $25 \mathrm{~mm}, 40-63 \mu \mathrm{m}$, Merck) to give compound 2 (7 mg). The fractions eluted with EtOAc (65 $\mathrm{mg}$ ) were purified on MPLC column using (LiChroprep Si 60, 310 × 25 mm, 40-63 $\mu \mathrm{m}$, Merck) to afford pure compound $\mathbf{1}(17 \mathrm{mg})$.

\section{Compound 1}

Yellowish solid, $\mathrm{mp}$ 280-281 ${ }^{\circ}, \mathrm{MS}: \mathrm{m} / \mathrm{z}$ (rel. int.\%) 380 (19) $[\mathrm{M}]^{+}$corresponding to the molecular formula of $\mathrm{C}_{21} \mathrm{H}_{16} \mathrm{O}_{7}$, NMR data: see Table 1.

\section{Compound 2}

Yellowish solid, mp 114-115,$[\alpha]_{\mathrm{D}}-$ $28.5^{\circ}(\mathrm{MeOH}, c$ 0.1), MS: $m / z$ (rel. int.\%) 362 (25) $[\mathrm{M}]^{+}$corresponding to the molecular formula of $\mathrm{C}_{20} \mathrm{H}_{26} \mathrm{O}_{6}$, NMR data: see Table 2.

Table 1: ${ }^{1} \mathrm{H}$ and ${ }^{13} \mathrm{C}$ chemical shift data of compound 1 (DMSO- $d_{6}$ ).

\begin{tabular}{|c|c|c|c|}
\hline No. & $\delta_{\mathrm{C}}$ (mult.) & $\delta_{\mathrm{H}}[$ mult., $J(\mathrm{~Hz})]$ & HMBC with $\mathrm{C}$ \\
\hline 1 & $169.6(\mathrm{C})$ & & \\
\hline 2 & $121.6(\mathrm{C})$ & & \\
\hline 3 & $118.6(\mathrm{C})$ & & \\
\hline 4 & $66.6\left(\mathrm{CH}_{2}\right)$ & $4.34(2 \mathrm{H}, \mathrm{s})$ & $\mathrm{C}-1, \mathrm{C}-2, \mathrm{C}-3, \mathrm{C}-5$ \\
\hline 5 & $129.4 *(\mathrm{C})$ & & \\
\hline 6 & $144.8(\mathrm{C})$ & & \\
\hline $\mathrm{HO}-6$ & & $10.39(1 \mathrm{H}, \mathrm{s})$ & $\mathrm{C}-6, \mathrm{C}-1^{\prime}$ \\
\hline $1^{\prime}$ & $123.2(\mathrm{C})$ & & \\
\hline $2^{\prime}$ & $100.7(\mathrm{CH})$ & $7.60(1 \mathrm{H}, \mathrm{s})$ & $\mathrm{C}-1^{\prime}, \mathrm{C}-4^{\prime}, \mathrm{C}-6^{\prime}$ \\
\hline $3^{\prime}$ & $150.4(\mathrm{C})$ & & \\
\hline $\mathrm{H}_{3} \mathrm{CO}-3^{\prime}$ & $55.7\left(\mathrm{CH}_{3}\right)$ & $3.92(3 \mathrm{H}, \mathrm{s})$ & $\mathrm{C}-3^{\prime}$ \\
\hline $4^{\prime}$ & $149.6(\mathrm{C})$ & & \\
\hline $\mathrm{H}_{3} \mathrm{CO}-4^{\prime}$ & $55.1\left(\mathrm{CH}_{3}\right)$ & $3.63(3 \mathrm{H}, \mathrm{s})$ & $C-4^{\prime}$ \\
\hline $5^{\prime}$ & $105.4(\mathrm{CH})$ & $6.93(1 \mathrm{H}, \mathrm{s})$ & $\mathrm{C}-5, \mathrm{C}-1^{\prime}, \mathrm{C}-3^{\prime}, \mathrm{C}-6^{\prime}$ \\
\hline $6^{\prime}$ & $129.4 *(\mathrm{C})$ & & \\
\hline $1^{\prime \prime}$ & $128.7(\mathrm{C})$ & & \\
\hline $2^{\prime \prime}$ & $111.1(\mathrm{CH})$ & $6.85(1 \mathrm{H}, \mathrm{brs})$ & C-5, C-4", C-6" \\
\hline $3^{\prime \prime}$ & $146.8(\mathrm{C})$ & & \\
\hline $4^{\prime \prime}$ & $146.5(\mathrm{C})$ & & \\
\hline $\mathrm{OH}_{2} \mathrm{CO}$ & $101.1\left(\mathrm{CH}_{2}\right)$ & $6.10(2 \mathrm{H}, \mathrm{s})$ & C-3", C-4" \\
\hline $5^{\prime \prime}$ & $107.8(\mathrm{CH})$ & $6.99(1 \mathrm{H}$, brd, 7.3$)$ & $C-1^{\prime \prime}, C-3^{\prime \prime}$ \\
\hline $6^{\prime \prime}$ & $123.7(\mathrm{CH})$ & $6.73(1 \mathrm{H}$, brd, 7.3$)$ & $\mathrm{C}-5, \mathrm{C}-4^{\prime \prime}$ \\
\hline
\end{tabular}

*Overlapped signals. 
Table 2: ${ }^{1} \mathrm{H}$ and ${ }^{13} \mathrm{C}$ chemical shift data of compound $2\left(\mathrm{CDCl}_{3}\right)$.

\begin{tabular}{|c|c|l||}
\hline No. & $\delta_{\mathrm{C}}($ mult. $)$ & $\delta_{\mathrm{H}}[$ mult., $J(\mathrm{~Hz})]$ \\
\hline 1,4 & $61.0\left(\mathrm{CH}_{2}\right)$ & $\begin{array}{l}3.85(2 \mathrm{H}, \mathrm{dd}, 11.1,2.5) \\
3.57(2 \mathrm{H}, \mathrm{dd}, 11.1,4.5)\end{array}$ \\
\hline $\mathrm{HO}-1 /-4$ & & $5.30(2 \mathrm{H}, \mathrm{s})$ \\
\hline 2,3 & $43.8(\mathrm{CH})$ & $1.85(2 \mathrm{H}, \mathrm{m})$ \\
\hline 5,6 & $35.9\left(\mathrm{CH}_{2}\right)$ & $2.74(2 \mathrm{H}, \mathrm{dd}, 14.0,8.0)$ \\
& & $2.64(2 \mathrm{H}, \mathrm{dd}, 14.0,6.5)$ \\
\hline $1^{\prime}, 1^{\prime \prime}$ & $132.4(\mathrm{C})$ & \\
\hline $2^{\prime}, 2^{\prime \prime}$ & $111.3(\mathrm{CH})$ & $6.58(2 \mathrm{H}, \mathrm{d}, 2.0)$ \\
\hline $3^{\prime}, 3^{\prime \prime}$ & $146.4(\mathrm{C})$ & \\
\hline $\mathrm{H}_{3} \mathrm{CO}-3^{\prime} /-3^{\prime \prime}$ & $55.8(\mathrm{CH})$ & $3.82(6 \mathrm{H}, \mathrm{s})$ \\
\hline $4^{\prime}, 4^{\prime \prime}$ & $143.8(\mathrm{C})$ & \\
\hline $\mathrm{HO}^{\prime} 4^{\prime} / 4^{\prime \prime}$ & & $5.50(2 \mathrm{H}, \mathrm{s})$ \\
\hline $5^{\prime}, 5^{\prime \prime}$ & $114.0(\mathrm{CH})$ & $6.80(2 \mathrm{H}, \mathrm{d}, 8.0)$ \\
\hline $6^{\prime}, 6^{\prime \prime}$ & $121.6(\mathrm{CH})$ & $6.63(2 \mathrm{H}, \mathrm{dd}, 8.0,2.0)$ \\
\hline \multicolumn{2}{|l}{}
\end{tabular}

\section{RESULTS AND DISCUSSION}

\section{Compound 1}

Compound 1 (Figure 1) was purified as yellowish solid. The EIMS displayed a molecular ion peak at $\mathrm{m} / \mathrm{z}, 380$, which was in consistent with the molecular formula of $\mathrm{C}_{21} \mathrm{H}_{16} \mathrm{O}_{7}$. The molecular formula of $\mathrm{C}_{21} \mathrm{H}_{16} \mathrm{O}_{7}$ requires 14 degrees of unsaturation, indicating the aromatic nature of 1 . The ${ }^{1} \mathrm{H}$ NMR spectrum of $1\left(D M S O-d_{6}\right)$ showed resonances for 16 protons (Table 1) including five aromatic signals (7.60-6.73 ppm), one oxygenated methylene at $\delta 4.34\left(\mathrm{~s}, \mathrm{OCH}_{2}\right)$, one methylenedioxy at $\delta 6.10\left(\mathrm{~s}, \mathrm{OCH}_{2} \mathrm{O}\right)$, two three-proton singlets at $\delta 3.92$ and $3.63(2 \mathrm{x}$ $\mathrm{OCH}_{3}$ ) together with a downfield exchangeable one-proton singlet $\delta 10.39(\mathrm{OH})$.<smiles>COc1cc(C[C@@H]2C[C@@H](Cc3ccc(O)c(OC)c3)[C@@H](CO)[C@@H]2CO)ccc1O</smiles>

Fig. 1: Structures of the isolated compounds 1 and 2.
The ${ }^{13} \mathrm{C}$ NMR spectrum of $\mathbf{1}$ displayed signals for 21 carbons including two methyls, two methylenes, five methines, and 12 quaternary carbons. With the exception of the signals of the methyls and methylenes, all signals appear in the aromatic region indicating the aromatic nature of $\mathbf{1}$.

Concrete interpretation of the ${ }^{1} \mathrm{H},{ }^{13} \mathrm{C}$ NMR, ${ }^{1} \mathrm{H}-{ }^{1} \mathrm{H}$ COSY and HMQC experiments allowed the interpretation of the five aromatic protons as an ABX system (H-2", H-5", and H$\left.6^{\prime \prime}\right)$ and two para-positioned protons ( $\mathrm{H}-2^{\prime}$ and $\left.\mathrm{H}-5^{\prime}\right)$, respectively. The protons at $\delta 6.85$ (brs, H-2'), 6.99 (brd, $7.3 \mathrm{~Hz}, \mathrm{H}-5^{\prime \prime}$ ), and 6.73 (brd, $\left.7.3 \mathrm{~Hz}, \mathrm{H}-6^{\prime \prime}\right)$ constitute the $\mathrm{ABX}$ system for the trisubstituted benzene moiety attached to $\mathrm{C}$ 5. In addition, the protons at $\delta 7.60\left(\mathrm{~s}, \mathrm{H}-2^{\prime}\right)$ and $6.93\left(\mathrm{~s}, \mathrm{H}-5^{\prime}\right)$, together with the two threeproton singlets at $3.92\left(\mathrm{H}_{3} \mathrm{CO}-3^{\prime}\right)$ and 3.63 $\left(\mathrm{H}_{3} \mathrm{CO}-4^{\prime}\right)$ constitute the fused benzene moiety at $\mathrm{C}-1^{\prime}$ and $\mathrm{C}-6^{\prime}$.

The placement of the substituents as well as the assignment of all quaternary carbons was unambiguously secured from the HMBC experiment (Table 1 and Figure 2). For examples, the placement of the lactone moiety $(\delta$ 169.6) at $\mathrm{C}-2$ was supported from $\mathrm{HMBC}$ correlations of $\mathrm{H}_{2}-4 / \mathrm{C}-1\left(\delta\right.$ 169.6), $\mathrm{H}_{2}-4 / \mathrm{C}-2$ ( $\delta$ 121.6), $\mathrm{H}_{2}-4 / \mathrm{C}-3\left(\delta\right.$ 118.6), and $\mathrm{H}_{2}-4 / \mathrm{C}-5(\delta$ 129.4). The placement of the $\mathrm{OH}$ moiety at $\mathrm{C}-6$ was secured from HMBC cross-peaks of $\mathrm{HO} / \mathrm{C}$ - 
$6(\delta 144.8), \mathrm{HO} / \mathrm{C}-1^{\prime}(\delta 123.2)$ as well as the downfield chemical shift of $\mathrm{O} H$ at $\delta 10.39$ due to the hydrogen bond formation with the lactone carbonyl (C-1) (Figure 2).
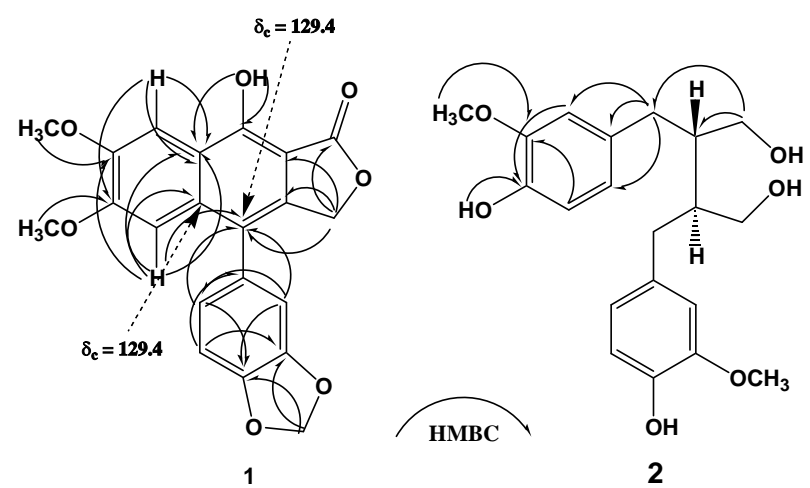

Fig. 2: Observed HMBC correlations of $\mathbf{1}$ and 2.

In addition, the placement of the two methoxyl moieties at C- $3^{\prime}$ and $\mathrm{C}-4^{\prime}$ was secured from HMBC cross-peaks of $\mathrm{H}_{3} \mathrm{CO}-3^{\prime} / \mathrm{C}-3^{\prime}$ ( $\delta$ $150.4), H_{3} \mathrm{CO}-4^{\prime} / \mathrm{C}-4^{\prime}$ ( $\delta$ 149.6), $\mathrm{H}-2^{\prime} / \mathrm{C} 4^{\prime}$, and $\mathrm{H}-5^{\prime} / \mathrm{C}-3^{\prime}$. Furthermore, the position of the methylenedioxy moiety at C-3" and C-4" was supported from $\mathrm{HMBC}$ cross-peaks of $\mathrm{OH}_{2} \mathrm{CO}$ $\left(\delta\right.$ 6.10)/C-3" $\left(\delta\right.$ 146.8), $\quad \mathrm{OH}_{2} \mathrm{CO} / \mathrm{C}-4 "{ }^{\prime \prime} \quad(\delta$ 146.5), H-6"/C-4", H-2"/C-4" and H-3"/C-5" (Figure 2).

The assignment of the overlapped signals for C-5 and C-6' at $\delta 129.4$ was secured from HMBC correlations of $\mathrm{H}-2^{\prime}\left(\delta\right.$ 7.60)/C- $6^{\prime}(\delta$ $129.4), \mathrm{H}-5^{\prime} / \mathrm{C}-6{ }^{\prime}, \mathrm{H}_{2}-4 / \mathrm{C}-5$ ( $\left.\delta 129.4\right), \mathrm{H}-2^{\prime \prime}(\delta$ $6.85) / \mathrm{C}-5, \mathrm{H}-6^{\prime \prime}\left(\delta\right.$ 6.73)/C-5 and $\mathrm{H}-5^{\prime} / \mathrm{C}-5$ (Figure 2).

Similarly, the assignment of the remaining quaternary carbons within $\mathbf{1}$ was secured from HMBC correlations. The HMBC correlations were showed in Table 1 and illustrated in Figure 2.

The above mentioned spectral data are in good agreement with the data reported for the synthetic compound (1-Hydroxy-3-(hydroxymethyl)-6,7-dimethoxy-4-(3,4-methylenedioxyphenyl)-2-naphthoic acid $\gamma$-lactone). ${ }^{12}$ For the best of our knowledge, this is the first report of this compound from a natural source.

\section{Compound 2}

Compound 2 (Figure 1) was purified as yellowish solid with a molecular formula of $\mathrm{C}_{20} \mathrm{H}_{26} \mathrm{O}_{6}$ as established from the EIMS $(\mathrm{m} / \mathrm{z}$ 362). The molecular formula of 2 requires eight degrees of unsaturation. Its ${ }^{1} \mathrm{H}$ NMR $\left(C D l_{3}\right)$ spectrum revealed resonances for 26 protons (Table 2). The ${ }^{13} \mathrm{C}$ NMR spectrum of 2 (Table 2) displayed 10 signals for the resonating carbons including three quaternary carbons, four methines, two methylenes, and one methyl. The existence of only 10 signals in the ${ }^{13} \mathrm{C}$ NMR spectrum for the molecular formula of $\mathrm{C}_{20} \mathrm{H}_{26} \mathrm{O}_{6}$ suggested the symmetrical dimeric nature of 2.

Interpretation of the ${ }^{1} \mathrm{H},{ }^{13} \mathrm{C}$ NMR, COSY, and HMQC revealed the presence of two spin coupling systems and allowed the assignment of all protonated carbon within 2. The resonating signals at $\delta 6.58\left(\mathrm{~d}, 2.0 \mathrm{~Hz}, \mathrm{H}-2^{\prime}\right)$, $6.80\left(\mathrm{~d}, 8.0 \mathrm{~Hz}, \mathrm{H}-5^{\prime}\right)$, and $6.63(\mathrm{dd}, 8.0,2.0$ $\mathrm{Hz}, \mathrm{H}-6^{\prime}$ ) constitute an $\mathrm{ABX}$ system for the trisubstituted benzene moiety (subunit A) (Figure 3). The second coupling system is formed of a methine proton $(\mathrm{H}-2)$ flanked with two methylenes $\left(\mathrm{H}_{2}-1\right.$ and $\left.\mathrm{H}_{2}-6\right)$ and forms a 2,3-disubstituted-1-propanol unit (subunit B) (Figure 3). These protons appear at $\delta 3.85$ (dd, 11.1, $2.5 \mathrm{~Hz}, \mathrm{H}-6 \mathrm{a}), 3.57$ (dd, 11.1, $4.5 \mathrm{~Hz}, \mathrm{H}-$ 6b), 1.85 (m, H-2), 2.74 (dd, 14.0, $8.0 \mathrm{~Hz}, \mathrm{H}-$ 1a), and 2.64 (dd, 14.0, $6.5 \mathrm{~Hz}, \mathrm{H}-1 \mathrm{~b}$ ). The connection of subunit $\mathbf{A}$ with subunit $\mathbf{B}$ at C1'/C6 to give the substructure $\mathbf{C}$ (Figure 3 ) was supported from $\mathrm{HMBC}$ cross-peaks of $\mathrm{H}_{2}-6 / \mathrm{C}$ $1^{\prime}, \mathrm{H}_{2}-6 / \mathrm{C}-2^{\prime}$, and $\mathrm{H}_{2}-6 / \mathrm{C}-5^{\prime}$ (Figure 2). Since compound $\mathbf{2}$ is a symmetrical dimmer, therefore the connection of the two halfs of $\mathbf{2}$ should be at $\mathrm{C}-2$ and $\mathrm{C}-3$ to give the entire structure of 2 (Figure 1).

The assignment of all quaternary carbons in 2 was supported from HMBC experiment (Figure 2). In addition, the placement of the $\mathrm{OH}$ and $\mathrm{OCH}_{3}$ moieties at C-4' and C-3', respectively was supported from $\mathrm{HMBC}$ correlations of $\mathrm{OCH}_{3} / \mathrm{C}-3^{\prime}(\delta$ 146.4), $\mathrm{HO}-4(\delta$ 5.5, s)/C-3' (143.8), H-2'/C-4', and H-5'/C-3'.

The above mentioned spectral data were in good agreement with the data reported for (-)secoisolariciresinol. ${ }^{13,14}$ For the best of our knowledge, this is the first report of this lignan from Haplophyllum tuberculatum (Forssk) A. Juss. 
<smiles>CCc1ccccc1</smiles>

A
- COSY correlation<smiles>CCCC(CC)CO</smiles>

B<smiles>COc1cc(CC(C)CO)ccc1O</smiles>

Fig. 3: $\quad{ }^{1} \mathrm{H}-{ }^{1} \mathrm{H}$ COSY correlations within subunits of 2.

The 1,4-butandiol lignan secoisolariciresinol (2) is a typical heartwood constituent of Gymnosperms, ${ }^{15}$ also reported, mainly in ester and glucosidic form, in many Angiosperms. ${ }^{16}$

\section{Anticancer evaluation of the compounds using in vitro Disk Diffusion Assay ${ }^{17,18}$ \\ The disk diffusion assay defines the} differential cell killing among the 7 cell types examined. These weretwo leukemias (murine L1210 and human CCRF-CEM), three solid tumors (murine Colon 38, human colon H116 and human lung H125), as well as a murine and human normal cell (hematopoietic progenitor cell, CFU-GM).

The sample $(15 \mu \mathrm{L}$, pure compound or extract) was placed on a filter disk that was placed on a matrix containing the cancer/normal cells. After 7-10 days of incubation, a zone of inhibition of colony formation was defined and quantified. Both antiproliferative response and differential activity are the end-points.

There are 4 possible positive outcomes: Murine solid tumor selectivity relative to leukemia, human solid tumor selectivity relative to leukemia; and, murine or human solid tumor selectivity relative to the normal cell. Any extract demonstrating all 4 selective outcomes is first priority for subsequent bioassay-directed fractionation. Similarly, any compound demonstrating all 4 selective outcomes is first priority for subsequent in vivo trials. Further, any human selectivity is prioritized over murine selectivities. The magnitude of the zonal difference as well as the potency is also used to prioritize the samples: the greater the differential and the greater the potency, the higher the priority. The assay was designed to determine large differences in the relative sensitivity of leukemias, solid tumors, and normal cell for a given sample. Preferably, we would like to observe a very large zone or total elimination of the solid tumor colonies from the plate and only minor toxicity for both the leukemia and normal cells.

The step-by-step laboratory methods for the assay of cell viability for the in vitro assay have been described. ${ }^{17,18}$ A short outline of that procedure is as follows:

\section{Preparation of cell suspensions}

Colon 38 gives a good monodispersed cell suspension with mechanical disruption from a mouse tumor. Colon 38 (approx. 1g) was cut into small fragments in $15 \mathrm{ml}$ of Hank's Balanced Salt Solution (HBSS) over a 100mesh sieve and gently forced through by the scissors with HBSS constantly perfusing the sieve. The material was then drawn into and out of a $5 \mathrm{ml}$ syringe without a needle to further disperse the cell clumps. It was then diluted and plated in 0.3\% agarose in DMEM plus $10 \%$ heat-inactivated Bovine Calf Serum (BCS). For plating of all of the cell types other than the normal CFU, the $60 \mathrm{~mm}$ plates were first prepared with a hard agar bottom layer (0.6\% agar in RPMI-1640 plus 15\% BCS).

The human colon cancer H116 and lung cancer H125 were maintained in cell culture. They were removed from their cultures by a trypsin-collagenase-DNAase cocktail. Their plating efficiencies were sufficiently high that 30,000 to 60,000 cells in $3 \mathrm{ml}$ produce the desired number of colonies (over 10,000 per plate) in the $60 \mathrm{~mm}$ plates. This soft agar top layer $(0.3 \%$ with the serum and media as above) plus the titrated tumor cells were poured into the plates and allowed to solidify.

For CFU-GM, the femoral marrow of BD2F1 mice was flushed with MEM-alpha; 2 $\mathrm{mL}$ per femur. The cells were passed through an 18-gauge needle twice and the monodispersed suspension counted. A total of $1.5 \times 10^{6}$ cells were plated in $3 \mathrm{ml}$ of $0.3 \%$ agar 
with the addition of $10 \%$ L-cell conditioned media, which provides colony stimulating factor, in MEM-alpha plus 10\% BCS. For human CFU-GM, the cells were obtained from Poietic Technologies, Inc. (Gaithersburg, MD) overnight and washed twice with PBS before being titered and added to the agar mixture. The same cell number, culture conditions, and conditioning factors were used as with the murine marrow.

\section{Sample preparation and Zone assay methodology}

The compounds ( $1 \mathrm{mg}$ ) were solubilized in $1 \mathrm{~mL}$ DMSO. A volume of $15 \mu \mathrm{L}$ of each sample was dropped onto a $6.5 \mathrm{~mm}$ disks (Baxter filter disks). The disks were allowed to dry overnight and then placed close to the edge of the petri dish. The plates were incubated for 7-10 days (depending upon the cell type) and examined by an inverted stereo-microscope (10X) for measurement of the zone of inhibition measured from the edge of the filter disk to the beginning of normal-sized colony formation. The diameter of the filter disk, 6.5 $\mathrm{mm}$, was arbitrarily taken as 200 units. A zone of less than 300 units was taken as the extract was of insufficient activity to be of further interest. A difference in zones between solid tumor cells and either normal or leukemia cells of 250 units defines solid tumor selective compounds. If the test material is excessively toxic at the first dosage, we then retest a range of dilutions of the agents (1:4 decrements) against the same tumors. At some dilutions, appropriate activity is invariably obtained. If it was necessary to dilute the sample 16-fold or greater to obtain a zone of 500 units against any solid tumor cells, the compound is termed potent.

\section{Results}

Compound 1 has proven to be a human solid tumor selective against human lung cancer $(\mathrm{H}-125 \mathrm{M})$ relative to normal cells (Table 3). Compound 2 showed neither potency nor selectivity in the disk diffusion assay.

Table 3: Results of in vitro anticancer evaluation of $\mathbf{1}$ and $\mathbf{2}$ using Disk Diffusion Assay.*

\begin{tabular}{|c|c|c|c|c|c|c|c||}
\hline \multirow{2}{*}{$\begin{array}{c}\text { Cancer/ } \\
\text { Normal } \\
\text { Cell }\end{array}$} & \multicolumn{2}{|c|}{ Leukemia } & \multicolumn{2}{c|}{ Murine/Human Solid Tumors } & \multicolumn{2}{c|}{ Normal Cells } \\
\cline { 2 - 8 } & $\begin{array}{c}\text { Lurine } \\
\text { (L1210) }\end{array}$ & $\begin{array}{c}\text { Human } \\
\text { Leukemia } \\
\text { (CCRF-CEM) }\end{array}$ & $\begin{array}{c}\text { Murine } \\
\text { Colon 38 }\end{array}$ & $\begin{array}{c}\text { Human } \\
\text { Colon } \\
\text { (H-116) }\end{array}$ & $\begin{array}{c}\text { Human } \\
\text { Lung } \\
(\mathrm{H}-125 \mathrm{M})\end{array}$ & $\begin{array}{c}\text { Murine } \\
\text { CEM }\end{array}$ & $\begin{array}{c}\text { Human } \\
\text { (CFU-GM) })\end{array}$ \\
\hline Compound & \multicolumn{7}{|c|}{ Inhibition Zone Expressed in Units } \\
\hline $\mathbf{1}$ & 500 & 500 & 700 & 600 & 700 & 400 & 500 \\
\hline $\mathbf{2}$ & 400 & 400 & 350 & 400 & 350 & 400 & 400 \\
\hline
\end{tabular}

*Numbers indicate Inhibition Zone units. 


\section{Acknowledgment}

I gratefully appreciate the taxonomic identification of the plant material by Prof. A. Fayed at Assiut University. $500 \mathrm{MHz}$ NMR and MS spectral determinations were kindly provided by $M$. Idelbi at University of Freiburg, Germany. I thank Prof. F. Valeriote at HFHS, Detroit, U.S.A. for the anticancer evaluation of the compounds.

\section{REFERENCES}

1- J. C. Willis, "A Dictionary of the Flowering Plants and Ferns", $8^{\text {th }}$ Ed., revised by H. K. A. Shaw, Cambridge University Press, Cambridge, 1980, p. 532.

2- V. Tackholm, "Students Flora of Egypt", Cairo University, 1974, p. 334.

3- M. A. Abd EL-Kawy, E. A. EL-Kashoury, A. M. EL-Fishawy, A. H. Atta and F. M. Soliman, Egypt. J. Pharm. Sci., 30, 299 (1989).

4- D. Lavie, N. Danieli, R. Weitman and E. Glotter, Tetrahedron, 24, 3011 (1968).

5- A. Al-Shamma, N. A. Al-Dauri and G. D. Phillipson, Phytochemistry, 18, 1417 (1979).

6- A. A. Khalifa, and D. T. A. Youssef, Bull. Pharm. Sci., Assiut University, 22, 157 (1999).

7- G. M. Sheriha, K. Abouamer, B. Z. ELShtaiwi, A. A. S. Ashour, F. A. Abe and H. H. AL-Hallaq, Phytochemistry, 26, 3339 (1987).
8- G. M. Sheriha, and K. Abouamer, ibid., 23, 151 (1984).

9- G. M. Sheriha, K. Abouamer and B. Z. EL-Shtaiwi, ibid., 24, 884 (1985).

10- S. A. Khalid and P. G Waterman, Planta Med., 43, 148 (1981).

11- L. Boulus, "Medicinal Plants of North Africa", Reference Publications Inc., Michigan, 1983, p. 155.

12- H. Zenichi, O. Kazuo, K. Sang-Won, M. Takefumi., Chem. Pharm. Bull., 17, 1878 (1969).

13- L. H. Brigges, R. C. Cambie, and J. L. Hoare, Tetrahedron Lett., 14 (1959).

14- H. Achenbach, R. Waibel, and I. AddaeMensah, Phytochemistry, 22, 749 (1983).

15- K. Freudenberg and K. Weinges, Tetrahedron Lett., 19 (1959).

16- R. C. Powell and R. D. Plattner, Phytochemistry, 15, 1963 (1976).

17- T. H. Corbett, F. A. Valeriote, L. Polin, et. al., Discovery of Solid Tumor Active Agents Using a Soft Agar Colony Formation Disk Diffusion Assay. In: Cytotoxic Anticancer Drugs: Models and Concepts for Drug Discovery and Development, F. A. Valeriote, T. H. Corbett and L. H. Baker (Ed.), Kluwer Acedemic Publishers, Boston/Dordrecht, London, 1992, pp. 33-87.

18- F. Valeriote, C. K. Greishaber, J. Media, H. Pietraszkewicz, J. Hoffman, M. Pan, and S. McLaughlin, J. Exp. Ther. Oncol., 2, 228 (2002). 